\title{
The evidence for hippocampal long-term potentiation as a basis of memory for simple tasks
}

\author{
IVÁN IZQUIERDO ${ }^{1}$, MARTÍN CAMMAROTA ${ }^{1}$, WEBER C. DA SILVA ${ }^{1}$, LIA R.M. BEVILAQUA ${ }^{1}$, \\ JANINE I. ROSSATO ${ }^{1}$, JULIANA S. BONINI ${ }^{1}$, PAMELA MELLO ${ }^{1}$, FERNANDO BENETTI ${ }^{1}$, \\ JADERSON C. $\operatorname{COSTA}^{1}$ and JORGE H. MEDINA ${ }^{2}$ \\ ${ }^{1}$ Centro de Memória, Instituto de Pesquisas Biomédicas, Pontifícia Universidade Católica do Rio Grande do Sul (PUCRS) \\ Av. Ipiranga, 6690, 90610-000 Porto Alegre, RS, Brasil \\ ${ }^{2}$ Instituto de Biologia Celular y Neurociência "Prof. Dr. Eduardo de Robertis", Facultad de Medicina \\ Universidad de Buenos Aires, Paraguay 2155, (1121) Buenos Aires, Argentina \\ Manuscript received on June 21, 2007; accepted for publication on August 13, 2007; \\ contributed by IVÁN IZQUIERDo* and JORGE H. MEDINA*
}

\begin{abstract}
Long-term potentiation (LTP) is the enhancement of postsynaptic responses for hours, days or weeks following the brief repetitive afferent stimulation of presynaptic afferents. It has been proposed many times over the last 30 years to be the basis of long-term memory. Several recent findings finally supported this hypothesis: a) memory formation of one-trial avoidance learning depends on a series of molecular steps in the CA1 region of the hippocampus almost identical to those of LTP in the same region; b) hippocampal LTP in this region accompanies memory formation of that task and of another similar task. However, CA1 LTP and the accompanying memory processes can be dissociated, and in addition plastic events in several other brain regions (amygdala, entorhinal cortex, parietal cortex) are also necessary for memory formation of the one-trial task, and perhaps of many others.
\end{abstract}

Key words: long-term potentiation, hippocampus, declarative memory, aversive memory.

\section{INTRODUCTION}

Long-term potentiation (LTP) was first described by Bliss and Lomo (1973) and Bliss and Gardner-Medwin (1973) in the dentate gyrus. It was recognized immediately as a possible model of memory, being the only stimulus-induced electrophysiological change that could last as long as a memory (see Matthies 1982, Bliss and Collingridge 1993, Reymann 1993). It consists of the enhancement of a postsynaptic response during many hours, days, or as it was later found, weeks (Barnes 1979) following a brief repetitive afferent stimulation. Subsequently LTP was seen in the CA3 region of the hippocampus (Alger and Teyler 1976), in the CA1 region

*Member Academia Brasileira de Ciências

Correspondence to: Iván Izquierdo

E-mail: izquier@terra.com.br
(Andersen et al. 1977), in the septo-hippocampal projection (Racine et al. 1983), and then in many regions of the cortex and in other places (Martin et al. 2000, Xin et al. 2006, Maroun 2006). LTP may even kindle silent synapses into action (Kasten et al. 2007). The opposite process, long-term depression (LTD) has also been recognized and proposed to play a role in learning (see Bliss and Collingridge 1993, Ito 2005, 2007, Steuber et al. 2007). It will be dealt with here only passingly. It is very prominent in cerebellum, where it has been best studied.

The widespread existence of LTP strengthened the views linking LTP with memory processes (Teyler and DiScenna 1987, Collingridge 1985, Malinow et al. 1988, Bliss and Collingridge 1993, Reymann 1993, Izquierdo and Medina 1995, 1997, Malenka and Nicholl 1999, 
Kandel and Squire 2000, Malenka 2003, Riedel et al. 2003, Malenka and Bear 2004). Formal theories were put forward in support of the idea that LTP actually underlies, or is an important component of, memory (Lynch and Baudry 1984, Frey and Morris 1997, Martin et al. 2000, Morris 2003, Morris et al. 2003, Martin and Clark 2007). In view of recent developments on the physiology of dendrite responses to different sources of stimulation (Sjöstreom and Hausser 2006, see also Nicholson et al. 2006), the theory most intriguing and with the largest chance of survival is that of synaptic tagging (Frey and Morris 1997, Morris et al. 2003). It presents a clear-cut physiological explanation of why synaptic activity leading to LTP in one pathway afferent to CA1 can influence synaptic activity brought in by another pathway.

In spite of the criticisms put forward by many (Keith and Rudy 1990, Martinez and Derrick 1996, see Barnes 1996 and Shors and Matzel 1997 for references), the LTP hypothesis of memory held firmly (Izquierdo and Medina 1995, 1997, Martin et al. 2000, Morris et al. 2003 ) and eventually was proven right (Gruart et al. 2006, Whitlock et al. 2006, Izquierdo et al. 2006). LTP does account for key aspects of memory; although, as will be seen, not all.

\section{THE MOLECULAR BASIS OF CA1 LTP}

Many studies have been carried out on the molecular basis of LTP in the CA1 region of the hippocampus and on the role of that region in the memory consolidation of one-trial avoidance learning (see above, and Ahmed and Frey 2005, Izquierdo et al. 2006 for references). The studies show remarkable similarities both in the nature and in the timing of the various molecular changes in LTP and in memory formation (Izquierdo and Medina 1995, 1997, Izquierdo and McGaugh 2000, Izquierdo et al. 2006).

CA1 LTP involves and requires initially an activation of AMPA, metabotropic and NMDA receptors in pyramidal cell synapses (Bliss and Collingridge 1993, Riedel et al. 2003). The induction of LTP is exquisitely sensitive to inhibition by GABAA receptors (see Teyler and DiScenna 1987, Bliss and Collingridge 1993 for references). The AMPA receptor activation depolarizes and thus renders NMDA receptors susceptible to glutamate action and thus permits the entry of $\mathrm{Ca} 2+$ to the cell. This causes a release of bound intracellular $\mathrm{Ca} 2+$; the high $[\mathrm{Ca} 2+]$ near the synaptic membrane stimulates the local activity of $\mathrm{Ca} 2+$-calmodulin-dependent protein kinase II (CaMKII), which promotes the phosphorylation of AMPA and other glutamate receptors (Barriá et al. 1997). Increased $\mathrm{Ca} 2+$ also occurs presynaptically, in which case it enhances the activity of protein kinase $\mathrm{C}$ (PKC), which phosphorylates the protein GAP-43, which further enhances glutamatergic transmission by mobilizing synaptic vesicles (Routtenberg 2000). Postsynaptically, PKC mediates further phosphorylation of glutamate receptors and eventually also the phosphorylation of the cAMP response element binding protein (CREB), a constitutive transcription factor (Roberson et al. 1999, see also Routtenberg 2000). The CaMKII change begins right after induction, and extends for 2-3 h (Barriá et al. 1997). The PKC changes peak at $30 \mathrm{~min}$ and extend for 1-2 $\mathrm{h}$ (Routtenberg 2000). At 3-4 $\mathrm{h}$ from training there is a dopaminergic D1 receptor stimulated increase of cAMP and of the cAMP-dependent protein kinase (PKA), which also phosphorylates CREB (Huang and Kandel 1995). There has been abundant evidence that ERK is activated at about the same time as PKA and that it is also essential for CA1 LTP maintenance and CREB (Selcher et al. 2004). BDNF and ERK may be upstream to mTOR signaling (Bekinschtein et al. 2007b), and which is crucial for hippocampal LTP (Tang et al. 2002).

For a possible role of zif268 in the transition between early and late LTP and in memory formation, see references in Izquierdo and Cammarota (2004). For references on a role of Arc, see Vazdarjanova et al. (2006).

The importance of CREB for the mRNA synthesis and subsequent protein synthesis that have long been held as necessary for the development of enduring neuronal plasticity (Kandel and Squire 2000) or, indeed, enduring memory formation (see Igaz et al. 2002 for references) has been repeatedly demonstrated (Bernabeu et al. 1997, Bozon et al. 2003). The role of mRNA synthesis and protein synthesis in CA1 LTP has been ascertained by numerous studies (see Huang and Kandel 1995). Among the many new proteins that are synthesized in CA1 following LTP or memory processing, there are those that result from the activation of early genes (fos, arc, jun, Src, zif268, etc. see above and Bozon et 
al. 2003), and a variety of first glyco- (O'Connell et al. 1997) and then sialoglycoproteins (Foley et al. 2003). These are believed to mold morphological changes at dendritic spines and/or the axon terminals that make synapse with them (see Rose 1995, Foley et al. 2003 for references). Such morphological changes have been suggested repeatedly to underlie the long-term maintenance both of LTP and memory (Kandel and Squire 2000, Bozon et al. 2003, Lynch et al. 2007). Morphological changes of hippocampal synapses (increased cell adhesion, bifurcation, and enlargement of both pre- and postsynaptic components, including receptor area), indeed accompany both LTP (Geinisman 2000) and memory formation processes (O’Connell et al. 1997, Foley et al. 2003). Undoubtedly all these changes suggest enhancement of synaptic function. The brain-derived neurotrophic factor (BDNF) is important for neuritogenesis as a whole, but particularly for the generation of the morphological changes at CA1 synapses that determine long-term maintenance of LTP (Santi et al. 2006, Rex et al. 2007, see also Lynch et al. 2007). The receptor for BDNF is tyrosine kinase B (TrkB) (Yamada and Nabeshima 2003, Brandner 2004), which activates the ERK pathway (Selcher et al. 2004, Sharma et al. 2006). This activation is necessary for the influence of BDNF on neuritogenesis (Alonso et al. 2004).

Granado et al. (2007) showed that D1R but not D5R are critical for hippocampal LTP and for the induction of Zif268 and Arc, proteins required for the transition from early to late LTP to L-LTP and for memory consolidation. For a possible role of zif268 in the transition between early and late LTP and in memory formation, see references in Izquierdo and Cammarota (2004). For references on a role of Arc, see Vazdarjanova et al. (2006).

Thus, the making and maintenance of CA1 LTP result from a well-timed and organized sequence of molecular events initiated by NMDA receptor activation and culminates by morphological changes at particular synapses in CA1 and elsewhere.

\section{THE CHOICE OF ONE-TRIAL AVOIDANCE AS THE TEST MODEL OF THE LTP HYPOTHESIS}

One-trial avoidance has long been a favorite for memory consolidation studies for several reasons: a) it is acquired in seconds but may last months (Izquierdo et al.
2003, Frankland et al. 2006), like LTP, b) it requires the participation of CA1, which is the region in which LTP has been best studied (Izquierdo and Medina 1997, Lorenzini et al. 1996); c) it is the task whose pharmacology has also been best studied (Izquierdo and McGaugh 2000), particularly in relation to or in search of a parallel with LTP (Izquierdo and Medina 1995, 1997, Izquierdo et al. 2006, 2007).

Therefore, it is not at all surprising that this task has been chosen as the model to test the LTP hypothesis of memory formation by Izquierdo et al. (2006) and Whitlock et al. (2006).

Other tasks in which the possibility that hippocampal CA1 LTP has also been proposed to play a key role in memory formation include, of course, spatial learning in a water maze (Morris et al. 1986), and classical eye blink conditioning (Tocco et al. 1991). Spatial learning in a water maze (the Morris maze) has long been known to depend on the hippocampus (Morris et al. 1986, 2003). Although the long-term storage of classical eyelid conditioning requires the cerebellum (Krupa and Thompson 1997), the earlier stages of memory formation of this task require alike events in the hippocampus of rabbits (Tocco et al. 1991, 1992). These events (increased AMPA binding) have been also reported after one-trial avoidance in rat CA1-CA3 (Cammarota et al. 1996, Izquierdo et al. 2006).

Due to the multi-trial nature of the task, a role for LTP in spatial learning is difficult to prove (Izquierdo et al. 2006). However, there are many preliminary and scattered findings in favor of such a role in that task (Morris 2003, Morris et al. 2003). On the other hand, a role of LTP of the CA3-CA1 pathway has been recently demonstrated in early classical eye blink conditioning by Gruart et al. (2006).

\section{CA1 LTP IN MEMORY CONSOLIDATION}

LTP of CA1 synaptic responses relevant to the memory being made has been recently observed in freely moving rats during consolidation of one-trial inhibitory avoidance (Whitlock et al. 2006). This fits with the simultaneous demonstration that the molecular requirements in CA1 for consolidation of that task are indeed almost if not completely identical to those of CA1 LTP (Izquierdo et al. 2006). 
For analogies and correspondences between the mechanisms of CA1 LTP and those observed in CA1 during the consolidation of one-trial inhibitory avoidance, see Reymann (1993) and Izquierdo and Medina (1995, 1997). See also in particular Izquierdo et al. (1992), Jerusalinsky et al. (1992), Bianchin et al. (1994), Cammarota et al. (1996) and specially Riedel et al. (2003) for the involvement of glutamate receptors in CA1; Cammarota et al. (2000) for the dependence of all the enzymatic changes observed (see below) on NMDA receptors activated at the time of training; Cammarota et al. (1997) for the role of PKC and GAP43; Cammarota et al. (1998) for the role of CaMKII; Bernabeu et al. (1997) and Taubenfeld et al. (2001) for the role of the PKACREB pathway; Ardenghi et al. (1997) and Bevilaqua et al. (1997) for the role of monoaminergic modulation of PKA (see below); Sweatt (2004), Alonso et al. (2002a, b) and Rossato et al.(2004) for the role of ERKs, which unlike CaMKII (Cammarota et al. 1998, Cammarota and Medina 2004) and PKA (Bernabeu et al. 1997, Vianna and Izquierdo 2004), is apparently related to the aversive aspects of the task (Alonso et al. 2002b), Izquierdo and Cammarota (2004), Bozon et al. (2003) and Vazdarjanova et al. (2006) for the role of early gene products; Igaz et al. (2002) for the need of mRNA and protein synthesis in hippocampus and their timing; Igaz et al. (2004) for posttraining protein synthesis in general (see below); Rose (1995), O'Connell et al. (1997) and specially Foley et al. (2003) for the posttraining role of glyco- and sialoglycoproteins in memory formation; Alonso et al. (2002a, 2005) for the role of BDNF in memory formation and Bekinschtein et al. (2007a) for hippocampal BDNF and memory persistence.

For the role of other enzymes related physiologically to PKC, PKA, CaMKII and the ERKs in memory formation and in LTP (i.e., Junkinase, Src kinase, etc.), see references in Izquierdo et al. (2006), Bevilaqua et al. (2003a, b, 2007). Importantly, mTOR signaling, perhaps stimulated by BDNF and ERKs, is crucial for the consolidation of one-trial avoidance (Bekinschtein 2007b), as has been shown to be crucial for LTP (Tang et al. 2002).

Concerning the genes that are activated and the corresponding proteins that are synthesized in the hippocampus as a consequence of behavioral training and/or memory consolidation, Igaz et al. (2004) have recently ob- served that CaMKII , Homer 1a, syntaxin 1a and ERK2 must be added to the list. These syntheses might involve reposition of enzymes that had been used by the learning process, or of other constitutive cell elements.

Certainly the observations of CA1 potentiation during classic eye blink conditioning in mice by Gruart et al. (2006) can be taken as a confirmation and an extension of the findings by Izquierdo et al. (2006) and Whitlock et al. (2006) on rat one-trial inhibitory avoidance and vice versa. Together, the three papers have strongly endorsed, to the point of actually proving, the LTP hypothesis of memory formation. (See, however, the last section below).

There have been three recent findings in the eye blink conditioning model. First, it was found that NMDA NR2B receptors in CA1 are involved both in the learning and the LTP that goes with it (Valenzuela-Harrington et al. 2007). These receptors had been previously shown to be involved in both inhibitory avoidance and spatial learning in the same area (Minichiello et al. 1999, Suetake-Koga et al. 2006). Second, it was reported that TrkB is crucially involved both in the eyelid conditioning and in the accompanying LTP (Gruart et al. 2007), as had been previously shown in this and other types of LTP and in avoidance and spatial tasks (see Brandner 2004). Third, and importantly, a dissociation was found in mice that hiperexpress TrkB between eyelid conditioning memory and the accompanying LTP; the former was depressed but the latter was unaltered (Sahun et al. 2007).

The first two findings on eyelid conditioning and CA1 LTP simply update findings in that task concerning both NR2B receptors and TrkB; both proteins have long been to play a key role in LTP and memory formation had been described in other tasks (see, for example, Fox et al. 2006 and Silhol et al. 2007, respectively). The third finding, that of dissociation between LTP and memory, is disquieting but potentially important (see below, last section).

It must be noted that there is much more certainty of the relation between LTP and memory formation at the systems level (see above) than at the cellular level. Given the complexity of the possible interplays between synaptic activation at one particular spine (Sjöstrom and Hausser 2006, Nicholson et al. 2006), and the possi- 
bility that silent synapses are activated by LTP (Kasten et al. 2007). The nature of the message relevant to a particular learning that becomes enhanced by LTP, be it in CA1 or anywhere else for that matter, becomes completely obscure. A possible role of cerebellar Purkinje cell LTD in the recognition of afferent patterns has been suggested by Steuber et al. (2007). Whatever happens in LTD could also happen, theoretically, in LTP; perhaps with a different sign (see Ito 2005, 2007).

It may however be overambitious to propose any such jump to the cellular level from what we know about the fundamental molecular mechanisms of memory in the hippocampus and other brain areas (Izquierdo et al. 2006). We know that the mechanisms of LTP involve protein synthesis leading to changes at synapses that can only be interpreted as underlying strengthening of the transmission across them (see Rose 1995, O’Connell et al. 1997, Geinisman 2000, Geinisman et al. 2004, Foley et al. 2003). This is certainly sufficient as a ground for memory formation and storage and to support general mechanisms and principles of memory storage. How are the changes then transmitted from the hippocampus and related structures to more distant areas of the brain (cerebral cortex, Izquierdo et al. 1997; cerebellum, Krupa and Thompson 1997) is another matter.

In this connection, we are not much better off than the physicians of eighty years ago, who could correctly diagnose that an infectious agent caused pneumonia; but did not know how or why it did, and what treatment to give. The treatments had not been discovered yet; as the pathways that harbor one or other memory have not been shown in detail either.

\section{LTP AND MEMORY OUTSIDE THE HIPPOCAMPUS}

There have been postulations of possible LTP in the basolateral amygdala in connection with the consolidation of conditioned fear tasks that require freezing as a response. Several authors proposed that, unlike inhibitory avoidance (McGaugh 2006), conditioned fear tasks that result in acquired freezing consolidate in the basolateral amygdala (Schafe et al. 2005, Wilenski et al. 2006, Phelps 2006). While this position is adhered to by a number of authors (eg., Phelps et al. 2004, Huang and Kandel 2007), it is vigorously contested by others (Vazdarjanova et al. 2001, Cahill et al. 2000, McGaugh,
2006), who advocate for a modulatory influence of the basolateral amygdala in fear- or otherwise aversivelymotivated memories. The discussion is not closed. It is possible that the amygdala may use some form or degree of storage in order to fulfill its modulatory role; but the evidence of the amygdale as a storage site is not compelling (see McGaugh 2006). In contrast, the evidence that the hippocampus is a storage site for aversive (Lorenzini et al. 1996, Izquierdo et al. 2006) as well as for a very wide variety of memories is overwhelming indeed. The amygdala as a regulator could be as important as the dopaminergic, noradrenergic and serotonergic pathways that end on D1, beta- and 1A re-ceptors respectively in $\mathrm{CA} 1$, the entorhinal cortex, the parietal cortex and other areas that make aversive and other memories. The receptors mentioned modulate cAMP levels and therefore the function of the cAMP-dependent protein kinase (PKA) that is central to memory making in the CA1 area and perhaps in the other regions mentioned as well (Ardenghi et al. 1997, Bevilaqua et al. 1997, Rossato et al. 2004, Izquierdo et al. 2006). Interestingly, neither the monoaminergic pathways nor their receptors, which are strongly linked to the consolidation of emotionally strong memories, including those of aversive nature, modulate memory formation of inhibitory avoidance and other tasks in the basolateral amygdala (Bevilaqua et al. 1997, Rossato et al. 2004, Izquierdo et al. 2006). Highly emotional memories, including aversive or otherwise high attention-demanding memories, are, as known, those best remembered by humans and animals (Hamann et al. 1997, Cahill and McGaugh 1998, Cahill et al. 1999). The dopaminergic D1 positive regulation of one-trial avoidance memory in CA1 has been confirmed by O'Carroll et al. (2006).

The mechanisms of LTP are far from identical in all places. There are important differences between dentate gyrus LTP, which was the first one to be described (Bliss and Lomo 1973), in CA3 LTP (Alger and Teyler 1976), and in CA1 LTP (Huang and Kandel 1995, 1996, see Izquierdo et al. 2006 for references). CA1 LTP is really triggered by glutamate action at NMDA receptors (Bliss and Collingridge 1993); NMDA-independent LTP is instead found in CA3 and elsewhere (Bortolotto et al. 2005). In contrast to the hippocampus, where it has not been described (see Huang and Kandel 1995, 
1996) and, if anything, an opposite effect of serotonin might be expected (Bernabeu et al. 1997, Izquierdo et al. 2006), in the amygdala the late maintenance phase of LTP is stimulated by a 5HT4 mediated mechanism which enhances both PKA and ERK activity (Huang and Kandel 2007). Modulation of this phase depends on dopamine D1 receptors in CA1 (Huang and Kandel 1995 ) and on $\beta$-noradrenergic processes in CA3 (Huang and Kandel 1996). CA3 and various other forms of LTP do not require NMDA receptor activation, which is indispensable for CA1 LTP (see Martin et al. 2000). Muscarinic- or nicotinic receptor-dependent LTP in mammalian ganglia has been described long ago, and seem not to require glutamate receptors at all (see Teyler and DiScenna, 1987). The amygdala and the ventromedial prefrontal cortex have reciprocal pathways that are important for the regulation of memory consolidation (Izquierdo et al. 2007) and extinction (Milad et al. 2007). The prefrontal-amygdala pathway normally generates LTD, which can be reversed into LTP by exposure to stress (Maroun 2006).

\section{ADDITIONAL COMMENT ON AGING AND PRION}

There is a decline in cognitive performance in rats and mice between the age of 2-3 months and that of 8 months attributable to a gradually increased sensitivity to downregulation by the PrPc protein (the physiological prion protein, Coitinho et al. 2003). Coincidentally, both posttetanic potentiation and LTP in the CA1 region of aging PrP-null mice are also reduced, which has been attributed to increased levels of oxidative stress in aged animals (Curtis et al. 2003). PrPc modulates memory consolidation in CA1 through an interaction with laminin (Coitinho et al. 2006) and with the stress-inducible protein 1 (Coitinho et al. 2007) resulting in changes of PKA and/or ERK function.

Monfort and Felipo (2007) have reported a diminution of the strength of CA1 LTP in normal rats between the age of 2 and 8 months, in which they detected an influence of sex (females were more resistant to the decline).

There are many things that age in the rat or the mouse between the age of 2 or 3 months and that of 8 or 9 months. Since these animals live for over 20-22 months (see Izquierdo et al. 2003), it is perhaps wiser to ascribe the changes that occur between 2 and 9 months to "maturation" rather than aging. The rift between maturation and aging is, of course, tenuous; and certainly most physiological changes seen in real aging are initiated much earlier. So it is possible that the decline of LTP (Monfort and Felipo 2007), and the decline of memory processes (Coitinho et al. 2003) seen before the age of 9 months may indicate early stages of those seen at an advanced (senile?) age (eg. Barnes 1979, Izquierdo et al. 2003). Sensitivity to regulation by PrPc may be one aspect of this progression.

\section{THERE ARE MORE THINGS}

A very large amount of evidence (Izquierdo et al. 1992, Jerusalinsky et al. 1992, Wolfman et al. 1994, Ardenghi et al. 1997, Bevilaqua et al. 1997, Izquierdo and Medina, 1997, Bonini et al. 2003, Rossato et al. 2004, Izquierdo et al. 2006, 2007) shows that glutamate receptor blockers, CaMKII, PKA, ERK inhibitors and other enzyme inhibitors, and a variety of drugs that block memory formation when given into the hippocampus, also block memory formation when given into the basolateral amygdala, entorhinal cortex, posterior parietal cortex and prefrontal cortex. The effect of all these drugs in these other structures has a very different timing from that observed in CA1 and characteristic of LTP. In fact, in all these other structures, the timing of their actions is incompatible with an influence on LTP or an LTP-like mechanism (Izquierdo et al. 2006).

Therefore, it must be concluded that a variety of the mechanisms typical of LTP can act independently of LTP, underlying other forms of plasticity in all the other brain areas mentioned, and that these mechanisms are also essential for the formation of one-trial inhibitory avoidance and perhaps of many other tasks (see above).

The molecular changes that underlie the consolidation of one-trial avoidance (Izquierdo et al. 2006) and other aversive tasks (Matthies 1982) are in general biphasic: there is a rapid posttraining peak of PKA (Bernabeu et al. 1997) and ERK (Alonso et al. 2002b) activity and RNA and protein synthesis (Quevedo et al. 1999, Igaz et al. 2002) followed by and a second peak 2-6 h later (Matthies 1982, Bernabeu et al. 1997, Cammarota et al. 2000, Igaz et al. 2002). The early peak of ERK is probably secondary to the aversive stimuli used for training 
(Alonso et al. 2002b). This is different from what is usually assumed to happen in LTP, in which there appears to be just one peak of molecular processes (Malinow et al. 1988), usually believed to be late, at 3-4 h from induction (Huang and Kandel 1995, 1996). Perhaps this difference is not functionally important from the point of view of a role of LTP in memory processing (Izquierdo et al. 2006). Perhaps the rapid early peak has not been sufficiently investigated in LTP; the effect of inhibitors has been much more studied in LTP than the actual biochemical changes.

In addition, the dissociation of CA1 LTP from the classical eye blink conditioning task that was seen in transgenic mice that overexpress TrkB (Sahun et al. 2007) clearly shows that LTP must be regarded not only as "the" mechanism of memory formation. It certainly is one mechanism of memory formation; but not the only one, and in addition LTP can function alone, without lending a basis to memory processes. For roles of LTP in other processes that do not necessarily involve memory formation, see Teyler and DiScenna (1987) and Shors and Matzel (1997).

It has been proposed long ago that different brain structures and processes therein may handle different aspects or components of each memory (Izquierdo et al. 1992, 2006). One-trial inhibitory learning, in spite of its simplicity, involves many such components and several of them can be distinguished mechanistically by different forms of training and treatments (eg. Roesler et al. 2005, 2006). The hippocampus may be in charge of spatial and contextual aspects (Morris et al. 1986, 2003, Martin and Clark 2007); the amygdala may be in charge of highly attentional and/or aversive components (Phelps 2006, see McGaugh 2006); the parietal cortex may be in charge of sensory signals or representations (Izquierdo et al. 2006); etc. It is possible, perhaps very likely, that each of these structures uses a different form of neural plasticity to handle these different components (see Izquierdo et al. 2006). Even within the hippocampal CA1 region NMDA-dependent and NMDA-independent processes can be recognized as separate for different aspects of one-trial memory (Roesler et al. 2005, 2006). The entorhinal cortex, by virtue of its interconnections with all of the areas mentioned (Hyman et al. 1990) may be the main connecting bridge between the various ar- eas, processes and functions. The famous amnestic case, H.M., who suffered a devastating bilateral temporal lobe surgery in 1953 and was left with an impossibility of making new declarative memories and a pronounced retrograde amnesia was examined by fMRI in 1996 and again last year by Corkin and her group. The lesions of H.M. comprised most if not all the entorhinal cortex on both sides and only part of the hippocampus (Corkin et al. 1997, Salat et al. 2006). In monkeys, too, bilateral entorhinal lesions cause much more amnesia than bilateral hippocampal or hippocampo-amygdalar resection (see Squire et al. 2004 for references). Patients with circumscribed hippocampal surgical lesions because of epilepsy seldom present any amnesia in any way comparable with that of H.M., if they present any amnesia at all (Paglioli et al. 2006). In fact, their postoperative memory performance is usually better than that of their preoperative life, when they were plagued by epileptic seizures (Tuon et al. 2007). Therefore the entorhinal cortex plays a role in memory larger than its fame. At least certainly larger than that of the hippocampus or amygdala.

Of a few things we can be sure. First, that there is LTP in memory, but there is much more to memory than hippocampal LTP. Second, that mechanisms outside the hippocampus are as important as those in that structure, and probably do not involve LTP. Third, that the ultimate storage of memory for weeks, months or years certainly is not in the hippocampus, but elsewhere in the brain, probably in the neocortex or in circuits that heavily involve the neocortex (Izquierdo et al. 1997, Squire et al. 2004). In the case of classic eye blink conditioning, which is made originally in the hippocampus (Tocco et al. 1991, 1992, Gruart et al. 2006, 2007), the ultimate storage is in the cerebellum (Krupa and Thompson 1997). In the case of one-trial avoidance, it is in the neocortex (Izquierdo et al. 1997. Therefore, it is not really necessary, or indeed believable, that the LTP involved in memory acquisition or consolidation should last as long as the memory itself. The search for storage mechanisms continues.

\section{RESUMO}

A potenciação de longa duração (LTP) é o aumento de respostas pós-sinápticas durante horas, dias ou semanas após a breve estimulação repetitiva de aferentes pre-sinápticos. Foi pro- 
posto durante 30 anos ser a base da memória de longa duração. Vários achados recentes finalmente apoiaram esta hipótese: a) a formação da memória de esquiva inibitória adquirida numa sessão depende de uma cadeia de processos moleculares na região CA1 do hipocampo quase idêntica à da LTP nessa mesma região; b) LTP hipocampal nessa região acompanha a formação da memóría dessa tarefa e de outra semelhante. No entanto, a LTP de CA1 e os processos de memória podem ser dissociados e, fora disso, processos plásticos em outras regiões cerebrais (amígdala, córtex entorrinal, córtex parietal) também são necessários para a formação da memória da tarefa de uma sessão e talvez de muitas outras.,

Palavras-chave: potenciação de longa duração, hipocampo, memória declarativa, memória aversiva.

\section{REFERENCES}

Ahmed T AND FReY JU. 2005. Plasticity-specific phosphorylation of CaMKII, MAP-kinases and CREB during lateLTP in rat hippocampal slices in vitro. Neuropharmacol 49: 477-492.

Alger BE AND TeYler TJ. 1976. Long-term and shortterm plasticity in the CA1, CA3 and dentate region of the rat hippocampal slice. Brain Res 110: 463-480.

Alonso M, Vianna MRM, Depino AM, Mello E Souza T, Pereira P, Szapiro G, Viola H, Pitossi F, IZQUierdo I AND MEdina JH. 2002a. BDNF-triggered events in the rat hippocampus are required for both short- and long-term memory formation. Hippocampus 12: $551-560$.

Alonso M, Viola H, IzQuierdo I and Medina JH. 2002b. Aversive experiences are associated with a rapad and transient activation of ERKs in the rat hippocampus. Neurobiol Learn Mem 77: 119-124.

Alonso M, Medina JH And Pozzo-Miller L. 2004. ERK $1 / 2$ activation is necessary for BDNF to increase dendritic spine density in hippocampal CA1 pyramidal neurons. Learn Mem 11: 172-178.

Alonso M, BeKinschtein P, Cammarota M, Vianna MRM, IZQUiERdo I AND MEdina JH. 2005. Endogenous BDNF is required for long-term memory formation in rat parietal cortex. Learn Mem 12: 504-510.

Andersen P, Sundberg SH, SWeEn O And Wigström H. 1977. Specific long-lasting potentiation of synaptic transmission in hippocampal slices. Nature 266: $736-$ 737.

Ardenghi P, Barros D, Izquierdo LA, Bevilqua LRM, Schröder N, Quevedo J, Rodrigues C,
Madruga M, Medina JH And IzQuierdo I. 1997. Late and prolonged memory modulation in entorhinal and parietal cortex by drugs acting on the cAMP/protein kinase A signaling pathway. Behav Pharmacol 8: 745-751.

BARNES CA. 1979. Memory deficits associated with senescence: A neurophysiological and behavioral study in the rat. J Comp Physiol Psychol 93: 74-104.

BARNES CA. 1996. Involvement of LTP in memory: Are we searching under the street light? Neuron 15: 751-754.

Barriá A, Muller D, Derkach V, Griffith LC AND SODERLING TR. 1997. Regulatory phosphorylation of AMPA-type glutamate receptors by CaM-KII during long-term potentiation. Science 276: 2042-2045.

Bekinschtein P, CAMmarota M, Igaz LM, BeVilaqua LRM, IZQUiERdo I AND MEdina JH. 2007a. Persistence of long-term memory storage requires a late protein synthesis- and BDNF-dependent phase in the hippocampus. Neuron 53: 261-267.

Bekinschtein P, Katche C, Slipczuk L, Igaz LM, Cammarota M, izquierdo I and Medina JH. 2007b. mTOR signaling in the hippocampus is necessary for memory formation. Neurobiol Learn Mem 27: 303307.

Bernabeu R, Bevilaqua L, Ardenghi P, Bromberg E, SCHMITZ PK, BIANCHIN M, IZQUiERdo I AND MEDINA JH. 1997. Involvement of hippocampal D1/D5 receptor - cAMP signaling pathways in a late memory consolidation phase of an aversively-motivated task in rats. Proc Natl Acad Sci USA 94: 7041-7046.

Bevilaqua L ET AL. 1997. Drugs that influence the cyclic adenosine monophosphate/protein kinase A signalling pathway alter memory consolidation when given late after training into rat hippocampus but not amygdala. Behav Pharmacol 8: 331-338.

Bevilaqua LRM, Rossato Ji, Medina JH, Izquierdo I AND CAMMAROTA M. 2003a. Src kinase activity is required for avoidance memory formation and recall. Behav Pharmacol 14: 639-652.

Bevilaqua LRM, Kerr DS, Medina JH, IzQuierdo I AND CAMMAROTA M. 2003b. Inhibition of hippocampal Jun N-terminal kinase enhances short-term memory but blocks long-term memory formation and retrieval of an inhibitory avoidance task. Eur J Neurosci 17: 897-902.

Bevilaqua LRM, Rossato Ji, Bonini JS, Da Silva WC, IzQuierdo I AND CAMmarota M. 2007. The role of JNK in the CA1 region of the hippocampus in extinction of inhibitory avoidance behavior. Behav Pharmacol 18: 483-489. 
Bianchin M, Da Silva RC, Schmitz PK, Medina JH AND IZQUIERDO I. 1994. Memory of inhibitory avoidance in the rat is regulated by glutamate metabotropic receptors in the hippocampus. Behav Pharmacol 5: 356359 .

Bliss TV And Collingridge GL. 1993. A synaptic model of memory: long-term potentiation in the hippocampus. Nature 361: 31-39.

BLISS TV AND GARDNER-MEDWIN AR. 1973. Long-lasting potentiation of synaptic perforant path. J Physiol 232: $327-374$.

BLISS TV AND LOMO T. 1973. Long-lasting potentiation of synaptic transmission in the dentate area of the anaesthetized rabbit following stimulation of the perforant path. J Physiol 232: 331-356.

Bonini JS, Rodrigues L, Kerr DS, BeVilaqua LR, CAMmARotA M AND IZQUIERdo I. 2003. AMPA/kainate and group-I metabotropic receptor antagonists infused into different brain areas impair memory formation of inhibitory avoidance in rats. Behav Pharmacol 14: 161-166.

Bortolotto ZA, Nistico R, More JC, Jane DE AND Collingridge GL. 2005. Kainate receptors and mossy fiber LTP. Neurotoxicology 26: 769-777.

Bozon B, Kelly A, Josselyn SA, Silva AJ, Davis S AND LAROCHE S. 2003. MAPK, CREB and zif268 are all required for the consolidation of recognition memory. Philos Trans R Soc Lond B Biol Sci 358: 805-814.

BRANDNER C. 2004. Nerve growth factors and neurotrophins. In: Riedel G and Platt B (Eds), From messengers to molecules, memories are made of these. Kluwer, New York, p. 286-299.

Cahill L and McGaugh JL. 1998. Mechanisms of emotional arousal and lasting declarative memory. Trends Neurosci 21: 294-299.

Cahill L, Weinberger N, RoozendaAl B And McGAUGH JL. 1999. Is the amygdala a locus of "conditioned fear?" Some questions and caveats. Neuron 23: 227-228.

Cahill L, Vazdarjanova A and Setlow B. 2000. The basolateral amygdala complex is involved with, but is not necessary for, rapid acquisition of Pavlovian 'fear conditioning'. Eur J Neurosci 12: 3044-3050.

Cammarota M And Medina JH. 2004. CaMK II. In: Riedel G and Platt B (Eds), From messengers to molecules, memories are made of these. Kluwer, New York, p. 283-410.

CAmmarota M, Bernabeu R, IzQuierdo I And MeDINA JH. 1996. Reversible changes in hippocampal
[3H]AMPA binding following inhibitory avoidance training in the rat. Neurobiol Learn Mem 66: 85-88.

Cammarota M, Paratcha G, Levi de Stein M, BerNABEU R, IZQUIERdo I AND MEdinA JH. 1997. B-50/ GAP-43 phosphorylation and PKC activity are increased in rat hippocampal synaptosomal membranes after an inhibitory avoidance training. Neurochem Res 22: 499505.

Cammarota M, Bernabeu R, Levi de Stein M, IzQUIERdo I AND MEDINA JH. 1998. Learning-specific, time-dependent increases in hippocampal $\mathrm{Ca} 2+/$ calmodulin dependent protein kinase II activity and AMPA GluR1 subunit immunoreactivity. Eur J Neurosci 10: 2669-2676.

Cammarota M, Bevilaqua LR, Ardenghi P, Paratcha G, LeVi de Stein M, IzQuierdo I AND MEDINA JH. 2000. Learning-associated activation of nuclear MAPK, CREB and Elk-1, along with Fos production, in the rat hippocampus after a one-trial avoidance learning: abolition by NMDA receptor blockade. Mol Brain Res 76: 36-46.

Coitinho AS, Roesler R, MARTins VR, BREnTANi RR AND IZQUIERDO I. 2003. Cellular prion protein impairs behavior as a function of age. Neuroreport 14: 13751379.

Coitinho as, Freitas aro, Lopes mh, haju GNM, Roesler R, Walz R, Rossatto Ji, Cammarota M, MARTINS VR AND BRENTANI RR. 2006. The interaction between prion protein and laminin modulates memory consolidation. Eur J Neurosci 24: 3255-3264.

Coitinho AS, Lopes MH, HaJj GNM, Rossato Ji, Freitas AR, Castro CC, Cammarota M, Brentani RR, IZQUIERDO I AND MARTINS VM. 2007. Short term memory formation and long term memory consolidation are enhanced by cellular prion association to stress inducible protein I. Neurobiol Dis 26: 282-290.

Collingridge GL. 1985. Long-term potentiation in the hippocampus: mechanisms of initiation and modulation by neurotransmitters. Trends Pharmacol Sci 6: 407-411.

Corkin S, Amaral DG, Gonzalez PG, Johnson KA AND HYMAN BT. 1997. H.M.'s medial temporal lobe lesion: findings from magnetic resonance imaging. J Neurosci 17: 3964-3979.

Curtis J, Errington M, Bliss T, Voss K and MaCLEOD N. 2003. Age-dependent loss of PTP and LTP in the hippocampus of PrP-null mice. Neurobiol Dis 13: 55-62. 
Foley AG, Ronn LC, Murphy KJ and Regan CM. 2003. Distribution of polysialylated neural cell adhesion molecule in rat septal nuclei and septo-hippocampal pathway: transient increase of polysialylated interneurons in the subtriangular septal zone during memory consolidation. J Neurosci Res 74: 806-817.

Fox CJ, Russell KI, WANG YT AND CHRISTIE BR. 2006. Contribution of NR2A and NR2B NMDA subunits to bidirectional synaptic plasticity in the hippocampus in vivo. Hippocampus 16: 907-915.

Frankland PW, Ding HK, Takahashi E, Suzuki A, KIDA S AND SILVA AJ. 2006. Stability of recent and remote contextual fear memory. Learn Mem 13: 451457.

FREY JU AND MORRIS RGM. 1997. Synaptic tagging and long-term potentiation. Nature 386: 533-536.

GeINISMAN Y. 2000. Structural synaptic modifications associated with LTP and behavioral learning. Cereb Cortex 10: 952-962.

GEINISMAN Y, GANESHINA O, YOSHIDA R, BERRY RW, Disterhoft JF And Gallagher M. 2004. Aging, spatial learning, and total synapse number in the rat CA1 stratum radiatum. Neurobiol Aging 25: 407-416.

Granado N, Ortiz O, SuÁrez LM, Martin ED, Cena V, Solís JM AND Moratalla R. 2007. D1 but not D5 Dopamine Receptors Are Critical for LTP, Spatial Learning, and LTP-Induced arc and zif268 Expression in the hippocampus. Cereb Cortex. EPub ahead of print march 2007.

Gruart A, MuÑoz MD AND Delgado-García JM. 2006. Involvement of the CA3-CA1 synapse in the acquisition of associative learning in behaving mice. J Neurosci 26: $1077-1087$.

Gruart A, Sciarretta C, Velenzuela-HarringTON M, Delgado-García JM AND Minichiello L. 2007. Mutation at the TrkB PLCgamma-docking site affects hippocampal LTP and associative learning in conscious mice. Learn Mem 14: 54-62.

Hamann SB, Cahill L and Squire LR. 1997. Emotional perception and memory in amnesia. Neuropsychol 11: $1-10$.

HUANG YY AND KANDEL ER. 1995. D1/D5 agonists induce a protein synthesis-dependent late potentiation in the CA1 region of the hippocampus Proc Natl Acad Sci USA 92: 2446-2450.

HUANG YY AND KANDEL ER. 1996. Modulation of both the early and the late phase of mossy fiber LTP by the activation of $\beta$-adrenergic receptors. Neuron 16: 611617.

HUANG YY AND KANDEL ER. 2007. 5-Hydroxytryptamine induces a protein kinase $\mathrm{A} /$ mitogen-activated protein kinase-mediated and macromolecular synthesis-dependent late phase of long-term potentiation in the amygdala. J Neurosci 27: 3111-3119.

Hyman BT, Van Hoesen GW and Damasio AR. 1990. Memory-related neural systems in Alzheimer's disease: an anatomic study. Neurology 40: 1721-1730.

IgAz LM, VIANNA MRM, MEdina JH AND IZQUiERdo I. 2002. Two time periods of hippocampal RNA synthesis are required for memory consolidation of fear-motivated learning. J Neurosci 22: 6781-6789.

IgAZ LM, BeKinschtein P, IZQUIERdo I AND MEdinA JH. 2004. One-trial aversive learning induces late change in hippocampal CaMKII, Homer 1a, Syntaxin 1a and ERK2 protein levels. Mol Brain Res 132: 1-12.

ITO M. 2005. Bases and implications of learning in the cerebellum-adaptive control and internal model mechanism. Progr Brain Res 148: 95-109.

Iто M. 2007. Cerebellar circuitry as a neuronal machine. Progr Neurobiol 78: 272-303.

IZQUIERDO I AND CAMMAROTA M. 2004. Zif and the survival of memory. Science 304: 829-830.

IZQUIERdo I AND MCGAUGH JL. 2000. Behavioural pharmacology and its contribution to the molecular basis of memory consolidation. Behav Pharmacol 12: 517-534.

IZQUIERdo I AND MEDINA JH. 1995. Correlation between the pharmacology of long-term potentiation and the pharmacology of memory. Neurobiol Learn Mem 63: 19-32.

IzQUiERdo I ANd Medina JH. 1997. Memory formation: the sequence of biochemical events in the hippocampus and its connection to activity in other brain structures. Neurobiol Learn Mem 68: 285-316.

IzQuierdo I, DA Cunha C, Rosat R, Jerusalisky D, FERREIRA MBC AND MEDINA JH. 1992. Neurotransmitter receptors involved in post-training memory processing by the amygdala, medial septum and hippocampus of the rat. Behav Neural Biol 58: 16-26.

IZQUiERdo I, QUILLFELDT JA, ZANATTA MS, QUEVEDO J, SchaefFer E, Schmitz PK AND Medina JH. 1997. Sequential involvement of hippocampus and amygdala, entorhinal cortex and parietal cortex in the formation and expression of memory for inhibitory avoidance in rats. Eur J Neurosci 9: 786-793. 
IZquierdo I, BEVILAQUA LRM, Rossato JI, BONINI JS, Medina JH and Cammarota M. 2006. Different molecular cascades in different sites of the brain control consolidation. Trends Neurosci 28: 496-505.

IZQUIERdo LA, BARROS DM, MEDINA JH AND IZQUIERDO I. 2003. Exposure to novelty enhances retrieval of very remote memory in rats. Neurobiol Learn Mem 79: $51-58$.

IZQUiERdo LA, BARros DM, DA COSTA JC, FURINI C, Zinn C, Cammarota M, Bevilaqua LRM AND IZQUIERDO I. 2007. A link between role of two prefrontal areas in immediate memory and in long-term memory consolidation. Neurobiol Learn Mem 88: 160-166.

Jerusalinsky D, Ferreira MBC, Walz R, Da Silva RC, Bianchin M, Ruschel A, Zanatta MS, MedINA JH AND IZQUIERDO I. 1992. Amnesia by posttraining infusion of glutamate receptor antagonists into the amygdala, hippocampus and entorhinal cortex. Behav Neural Biol 58: 76-80

KANDEL ER AND SQUiRE LR. 2000. Neuroscience: breaking down scientific barriers to the study of brain and mind. Science 290: 1113-1120.

Kasten MR, Fan Y and Schulz PE. 2007. Activation of silent synapses with sustained but not decremental longterm potentiation. Neurosci Lett 417: 64-89.

KEITH JR AND RUDY JW. 1990. Why NMDA-receptordependent long-term potentiation may not be a mechanism of learning and memory: Reappraisal of the NMDAreceptor blockade strategy. Psychobiology 18: 251-257.

KRUPA DJ AND THOMPSON RF. 1997. Reversible inactivation of the cerebellar interpositus nucleus completely prevents acquisition of the classically conditioned eye-blink response. Learn Mem 3: 545-556.

LORENZINI CA, BALDI E, BUCCHERELLI C AND TASSONI G. 1996. Role of dorsal hippocampus in acquisition, consolidation and retrieval of rat's passive avoidance response: A tetrodotoxin functional inactivation study. Brain Res 730: 32-39.

LYNCH G AND BAUDRY M. 1984. The biochemistry of memory: a new and specific hypothesis. Science 224 : 1057-1063.

LYNCH G, REX CS AND GALl CM. 2007. LTP consolidation: substrates, explanatory power, and functional significance. Neuropharmacol 52: 12-23.

MaLenKA RC. 2003. The long-term potential of LTP. Nature Rev Neurosci 4: 923-926.

MALENKA RC AND BEAR MF. 2004. LTP and LTD: an embarrassment of riches. Neuron 44: 5-21.
MALENKA RC AND NiCHOLl RA. 1999. Long-term potentiation - a decade of progress? Science 285: 1870-1974.

Malinow R, Madison DV and Tsien RW. 1988. Persistent protein kinase activity underlying long-term potentiation. Nature 335: 820-884.

MAROUN M. 2006. Stress reverses plasticity in the pathway projecting from the ventromedial prefrontal cortex to the basolateral amygdala. Eur J Neurosci 24: 2917-2922.

Martin SJ AND Clark RE. 2007. The rodent hippocampus: from synapses to systems. Cell Mol Life Sci 64: 401-431.

Martin SJ, GRIMWOOd PG AND MORRIS RG. 2000. Synaptic plasticity and memory: an evaluation of the hypothesis. Ann Rev Neurosci 23: 649-711.

MARTINEZ JL AND DERRICK BE. 1996. Long-term potentiation and learning. Ann Rev Psychol 47: 173-203.

Matthies H. 1982. Plasticity in the nervous system - An approach to memory research. In: AJMONE-MARSAN C AND MatThiEs H(Eds), Neuronal plasticity and memory formation. Raven Press, New York, p. 1-15.

MCGAUGH JL. 2006. Make mild moments memorable: add a little arousal. Trends Cogn Sci 10: 345-347.

Milad MR, Wright CI, ORR SP, PITMAN RK, QUiRK GJ AND RAUCH SL. 2007. Recall of Fear Extinction in Humans Activates the Ventromedial Prefrontal Cortex and Hippocampus in Concert. Biol Psychiatry 62: 446-454.

Minichiello L, Korte M, Wolfer D, Kuhn R, UNSiCKer K, Cestari V, Rossi-ARnaud C, LipP HP, BONHOEFFER T AND KLEIN R. 1999. Essential role for TrkB receptors in hippocampus-mediated learning. Neuron 24: 401-404.

MONFORT P AND FELIPo V. 2007. Hippocampal long-term potentiation is reduced in mature compared to young male rats but not in female rats. Neuroscience 146: 504-508.

MORRIS RG. 2003. Long-term potentiation and memory. Philos Trans R Soc Lond B Biol Sci 358: 643-647.

Morris RG, ANDERSON E, LYNCH GS AND BAUdRY M. 1986. Selective impairment of learning and blockade of long-term potentiation by an N-methyl-D-aspartate antagonist, Ap-5. Nature 319: 774-776.

Morris RG, Moser EI, Riedel G, Martin SJ, SANdin J, DAY M AND O'CARRoll C. 2003. Elements of a neurobiological theory of the hippocampus: the role of activity-dependent synaptic plasticity in memory. Philos Trans R Soc Lond. B Biol Sci 358: 773-786.

Nicholson Da, Trana R, Katz Y, Kath WL, SprusTON N AND GeINISMAN Y. 2006. Distance-dependent 
differences in synapse number and AMPA receptor expression in hippocampal CA1 pyramidal neurons. Neuron 50: 431-442.

O'Carroll CM, Martin SJ, Sandin J, Frenguelli B AND MORRIS RG. 2006. Dopaminergic modulation of the persistence of one-trial hippocampus-dependent memory. Learn Mem 13: 760-769.

O'Connell, O'Malley A and Regan CM. 1997. Transient learning-induced ultrastructural change in spatiallyclustered dentate gyrus cells of adult hippocampus. Neurosci 76: 55-62.

Paglioli e, Palmini A, Portuguez M, Paglioli E, Azambuja N, Da Costa JC, da Silva Filho HF, Martinez JV and Hoeffel R. 2006. Seizure and memory outcome following temporal lobe surgery: Selective compared with nonselective approaches for hippocampal sclerosis. J Neurosurg 104: 70-78.

PhelPS EA. 2006. Emotion and cognition: insights from studies of the human amygdala. Ann Rev Psychol 57: $27-53$.

Phelps EA, Delgado MR, Nearing KI And Le Doux JE. 2004. Extinction learning in humans: role of the amygdala and vmPFC. Neuron 43: 897-905.

Quevedo J, Vianna MRM, Roesler R, De-Paris F, IZQUIERDO I AND Rose SPR. 1999. Two time windows for anisomycin-induced amnesia for inhibitory avoidance training in rats: Protection from amnesia by pretraining but not pre-exposure to the task apparatus. Learn Mem 6: 600-607.

Racine RJ, Milgram NW and Hafner S. 1983. Longterm potentiation phenomena in the rat limbic forebrain. Brain Res 260: 217-231.

Rex CS, Lin CY, Kramar EA, Chen LY, Gall CM and LYNCH G. 2007. Brain-derived neurotrophic factor promotes long-term potentiation-related cytoskeletal changes in adult hippocampus. J Neurosci 27: 3017-3029.

REYMANN KG. 1993. Mechanisms underlying synaptic long-term potentiation in the hippocampus: Focus on postsynaptic glutamate receptors and protein kinases. Functional Neurol 8: 7-32.

Riedel G, Platt B and Micheau J. 2003. Glutamate receptor function in learning and memory. Behav Brain Res 140: 1-47.

Roberson ED, English JD, Adams JC, Selcher JC, Kondratick C And SweatT JD. 1999. The mitogenactivated protein kinase cascade couples PKA and PKC to cAMP response element binding protein phosphorylation in area CA1 of hippocampus. J Neurosci 19: 4337-4348.
Roesler R, Reolon GK, Luft T, Martins MR, Schroder N, Vianna MR AND Quevedo J. 2005. NMDA receptors mediate consolidation of contextual memory in the hippocampus after context preexposure. Neurochem Res 30: 1407-1411.

Roesler R, Vianna Mr, Schroder N, Ferreira MB AND Quevedo J. 2006. Aversive Learning under Different Training Conditions: Effects of NMDA Receptor Blockade in Area CA1 of the hippocampus. Neurochem Res 31: 679-683.

Rose SPR. 1995. Cell-adhesion molecules, glucocorticoids and long-term memory formation. Trends Neurosci 18 : 502-506.

Rossato Ji, Bonini JS, Coitinho AS, Vianna MR, Medina JH, CAmmarota M AND IZQUiERdo I. 2004. Retrograde amnesia induced by drugs acting on different molecular systems. Behav Neurosci 118: 563-568.

Routtenberg A. 2000. It's about time. In: Gold PE AND Greenough WT (Eds). Memory consolidation. American Psychological Association, Washington, p. 17-34.

Sahun I, Delgado-García JM, Amador-Arjona A, Giralt A, Al-Berch J, Dierssen M and Gruart A. 2007. Dissociation between CA3-CA1 synaptic plasticity and associative learning in TgNTRK3 transgenic ice. J Neurosci 27: 2253-2260.

Salat DH, van der Kouwe AJ, Tuch DS, Quinn BT, Fischl B, Dale AM and CoRkin S. 2006. Neuroimaging H.M.: a 10-year follow-up examination. Hippocampus 16: 936-945.

Santi S, Cappello S, Riccio M, Bergami M, Aicardi G, Schenk U, Matteoli M and Canossa M. 2006. Hippocampal neurons recycle BDNF for activity-dependent secretion and LTP maintenance. EMBO J 25: 4372-4380.

Schafe GE, Doyere V and Le Doux JE. 2005. Tracking the fear engram: the lateral amygdala is an essential locus of fear memory storage. J Neurosci 25: 10010-10014.

Selcher JC, Weeber EJ AND Sweatt JD. 2004. MAP kinases. In: Riedel G and Platt B (Eds), From messengers to molecules, memories are made of these. Kluwer, New York, p. 425-447.

Sharma SK, Sherff CM, Stough S, Hsuan V and CAREW TJ. 2006. A tropomyosin-related kinase B ligand is required for ERK activation, long-term synaptic facilitation, and long-term memory in aplysia. Proc Natl Acad Sci USA 103: 13206-14210.

ShORS TJ AND MATZEL LD. 1997. Long-term potentiation: What's learning got to do with it? Behav Brain Sci 20: 597-655. 
Silhol M, Arancibia S, Maurice T and Tapia-AranCIBIA L. 2007. Spatial memory training modifies the expression of brain-derived neurotrophic factor tyrosine kinase receptors in young and aged rats. Neuroscience 146: 962-973.

SJÖSTROM PJ AND HaUSSER M. 2006. A cooperative switch determines the sign of synaptic plasticity in distal dendrites of neocortical pyramidal neurons. Neuron 51: 153-155.

Squire LR, StARK CE AND ClARK RE. 2004. The medial temporal lobe. Ann Rev Neurosci 27: 279-306.

Steuber V, Mittmann W, Hoebeek Fe, Silver RA, De Zeeuw CL, Hausser M and De Schutter E. 2007. Cerebellar LTD and Pattern Recognition by Purkinje Cells. Neuron 54: 121-136.

Suetake-Koga S, Shimazaki T, Takamori K, Chaki S, Kanuma K, Sekiguchi Y, Suzuki T, Kikuchi T, MATSUI Y AND HONDA T. 2006. In vitro and antinociceptive profile of HON0001, an orally active NMDA receptor NR2B subunit antagonist. Pharmacol Biochem Behav 84: 134-141.

SWEATT JD. 2004. Mitogen-activated protein kinases in synaptic plasticity and mem-ory. Curr Opin Neurobiol 14: 311-317.

TANG SJ, Reis G, KAng H, Gingras AC, Sonenberg N AND SCHUMAN EM. 2002. A rapamycin-sensitive signaling pathway contributes to long-term synaptic plasticity in the hippocampus. Proc Natl Acad Sci USA 99: 467-472.

Taubenfeld SM, Milekic MH, Monti B And AlbeRINI CM. 2001. The consolidation of new but not reactivated memory requires hippocampal C/EBPbeta. Nat Neurosci 4: 813-818.

Teyler TJ ANd Discenna P. 1987. Long-term potentiation. Ann Rev Physiol 10: 131-161.

Tocco G, Devgan KK, Hauge SA, Weise C, Baudry M AND THOMPSON RF. 1991. Classical conditioning selectively increases AMPA receptor binding in the rabbit hippocampus. Brain Res 559: 331-336.

TOCCO G, MAREN G, SHORS TJ, BAUdRY M AND THOMPSON RF. 1992. Long-term potentiation is associated with increased [3 H]AMPA binding in rat hippocampus. Brain Res 573: 228-234.

Tuon L, Portuguez MW, Izquierdo I And da Costa JC. 2007. A new spatial orientation memory test: Evaluation in patients with mild Alzheimer's disease and in patients with operated and unoperated mesial temporal lobe epilepsy. Eur J Psychiat 21: 134-142.
VAlenzuela-Harrington M, Gruart A AND DelgaDO-GARCÍA JM. 2007. Contribution of NMDA receptor NR2B subunit to synaptic plasticity during associative learning in behaving rats. Eur J Neurosci 25: 830-836.

Vazdarjanova A, Cahill L and McGaugh JL. 2001. Disrupting basolateral amygdala function impairs unconditioned freezing and avoidance in rats. Eur J Neurosci 14: 709-18.

VAZDARJANOVA A, RAMIREZ-AMAYA V, INSEL N, Plummer TK, Posi S, Chowdury S, Mikhael D, Worley PF, Guzowski JF AND BARNes CA. 2006. Spatial exploration induces ARC, a plasticity-related immediate-early gene, only in calcium/calmodulindependent protein kinase II-positive principal excitatory and inhibitory neurons of the rat forebrain. J Comp Neurol 498: 317-329.

Vianna MRM ANd IzQUierdo I. 2004. Protein kinase A. In: Riedel G and Platt B (Eds), From messengers to molecules, memories are made of these. Kluwer, New York, p. 369-382.

Whitlock JR, Heynen AJ, Schuler MG And BeAR MF. 2006. Learning induces long-term potentiation in the hippocampus. Science 313: 1058-1059.

Wilensky AE, Wilensky AE, Schafe GE, KristenSEN MP AND LE DouX JE. 2006. Rethinking the fear circuit: the central nucleus of the amygdala is required for the acquisition, consolidation, and expression of Pavlovian fear conditioning. J Neurosci 26: 12387-12396.

Wolfman C, Fin C, Dias M, Bianchin M, DA Silva RC, Schmitz PK, Medina JH ANd IzQuierdo I. 1994. Intrahippocampal or intra-amygdala infusion of KN62, a specific inhibitor of calcium/calmodulin dependent protein kinase II, causes retrograde amnesia in the rat. Behav Neural Biol 61: 203-205.

Xin WJ, Gong QJ, Xu JT, Yang HW, Zang Y, Zhang T, LI YY AND LIU XG. 2006. Role of phosphorylation of ERK in induction and maintenance of LTP of the C-fiber evoked field potentials in spinal dorsal horn. J Neurosci Res 84: 934-943.

Yamada K And Nabeshima T. 2003. Brain-derived neurotrophic factor/TrkB signaling in memory processes. J Pharmacol Sci 91: 267-270. 